\title{
Introduction between Ban and Human Rights
}

\author{
The Regulation of Home-based Work Since the Twentieth Century
}

\author{
Silke Neunsinger
}

The history of home-based work predicts the future of labour, prefiguring the precariousness, the lack of protection, and time and wage theft, as well as the placing of the burden for working conditions on the independent subcontractor. These features are seen in many sectors of the labour market all over the world. While the parcelling out of specific jobs in the production process through subcontracting in such a manner that a part of the production shifted into the homes of workers was characteristic of industrial capitalism from the very start, the bad working conditions, low wages, and poor health and safety conditions did not generate international debate on a large scale until the early years of the twentieth century. This, though home-based work certainly received attention, even if limited, in the nineteenth century. For example, Marx in Das Kapital wrote about the predicaments of home-based workers. But it was not until the beginning of the twentieth century that the home-based worker became central to "the social question" in Europe, and a poster-child, as it were, for all the ills associated with industrialization.

For a long time, law and social policy distinguished between familybased work, which was widely accepted, and home work, which was not. Employers argued against the regulation of home-based work on the plea that it would violate the sanctity and privacy of the home. As far back as in 1923, the International Federation of Working Women (IFWW) requested the International Labour Office (ILO) to investigate the conditions of homebased work. However, it was only in the 1980s that trade unions in the global North, which had to begin with demanded the abolition of home-based work, changed their standpoint to push for regulation.

European investigators carried out a large number of national studies in different parts of Europe on the situation of home-based industrial workers. Trade union activist Jeanne Bouvier, whose life and work are discussed in Maria Tambouko's chapter in this volume ("Genealogies and assemblages of resistance:Jeanne Bouvier's struggles in 'le travail à domicile' ”), deployed these studies to draw the attention of the international trade union movement to the subject of home-based work and home workers. Several exhibitions were

(C) SILKE NEUNSINGER, 2022 | DOI:10.1163/9789004499614_008

This is an open access chapter distributed under the terms of the CC BY-NC-ND 4.o license. 
held that displayed the work and situation of home workers in early twentiethcentury Europe. These exhibitions, studies, and surveys were arranged and conducted by NGOS, state agencies, and trade unions - at times, by all three in collaboration. All three players, not least the trade unions, seem to have grappled with the same dilemma, namely: how are we to view these workers? Are they "victims" to be "saved", or workers to be organized? Do we argue for a ban or push for better conditions? The dilemma persisted even as many trade unions continued to function on the premise that home workers were "nonworkers" serving to drive down wages.

One of the first conferences on industrial home workers was held in Brussels in 1910, when the International Office for Industrial Homework was set up. In 1919, with the foundation of the ILO, home work became a part of the discussions around the subject of regulating work. This section deals with struggles for the recognition of home-based industrial workers and the regulation of their work. In three chapters, the authors discuss why it has been so difficult to regulate home-based labour, and question why the regulations took such a long time.

The home itself has often appeared as the reason for the lack of regulation. Traditionally, the ILO's setting of work standards was concerned with the conditions of male industrial workers in the global North. Many argued that it would be difficult to come up with standards for home work as it would be impossible to monitor work inside people's homes. However, some countries had already passed laws and included home-based workers under wage boards during the interwar period. And a few countries did regulate home work even though monitoring work in private homes was regarded as difficult in general. Depending on the relations between state, union and employers, state inspection of private homes was actually used as a way of regulating home work. This was the case in Norway. In Sweden, the unions were strong and against any form of state intervention; therefore, inspections were not carried out.

Regulation has manifested in three different ways. First, there is special legislation to protect home workers. This was the case with respect to the 1958 law in Italy, analysed in Eloisa Betti's chapter in this volume ("Industrial Home Work and Fordism in Western Europe: Women's Agency, Labour Legislation and Trade Union Action in Golden Age Italy, 1945-75"), and later in Thailand, as shown in Narumol Nirathron's study ("Home Work in Thailand: Challenges to Formalization"). Second, there is the amending of labour laws to include home workers and to make them equal to other workers. Efforts to do this can be seen in the 1973 law in Italy or the Bulgarian legislation, discussed in the chapter by Marlese von Broembsen and Jenna Harvey ("Realizing Rights for Home Workers: Participating in Global Supply Chains"). Third, through 
regulation of the entire chain of production including the conditions of homebased workers-independently of where they are based-as in the case of Australia, also analysed by von Broembsen and Harvey.

Home-based work and domestic work were the most common occupations of women in the early twentieth century in many urban settings. Both these forms of work also have a common feature: that the workplace is the home. While it is the worker's own home in the former instance, in the latter case it is the house of someone else, who is also the employer. However, regulations relating to domestic work and home-based work took different paths. This could be explained by the growth of the two forms of work at different points of time. Domestic work was never sought to be regulated by a ban, rather the opposite. When women chose to go to factories instead of working as live-in domestic servants, many European states opted for regulation of the working hours of domestic workers, in order to improve their working conditions and to make them stay. The growth of domestic workers in the Northern Transatlantic region during the last thirty years and their organizing on a global scale put the demand of domestic workers for decent work on the ILO's agenda; the ILO convention 189 was adopted in 2011, recognizing domestic workers as ordinary workers. Fifteen years earlier, in 1996, the ILO had recognized home-based industrial workers as ordinary workers. Eileen Boris's analysis of the debates at the ILO shows how initially, a ban on home-based industrial work had appeared inevitable, but changed circumstances after the Second World War eventually led to action. Important factors included a human rights approach, the push for action from staff of the Programme on Rural Women at the ILO, and the strategies adopted by women trade union activists and women's organizations, including the Self Employed Women's Association (SEWA); the former International Confederation of Free Trade Unions (ICFTU), now International Trade Union Confederation (ITUC); Women in Informal Employment: Globalizing and Organizing (WIEgo); the International Union of Food, Agricultural, Hotel, Restaurant, Catering, Tobacco and Allied Workers' Associations (IUF); and the International Textile, Garment and Leather Workers' Federation (IT GLWF). The efforts of these groups brought the issue to the table of the ILO. As in the case of domestic workers, women from the global South played a crucial role in this struggle.

Some unions regarded home work as a system to evade standards, and, as the chapter on Italy shows, employers closed factories and moved work to private homes, replacing men workers with cheaper women workers. Unions acted against such home work, but Betti shows that home workers started to protest the precarity of their working conditions and the lack of recognition. 
During the 1970s and 1980s home work was still seen as undermining factory work according to trade unions and international trade secretariats such as the ITGLWF. The change in strategy-from pushing for a ban to regulation-was driven not only by the growth of home work, but also, as Boris presents, by the work put in by feminists at the ILO and networks of female trade unionists, especially SEWA in India, led by the inimitable Ela Bhatt. These, together, managed to push for a focus on the demands of home-based workers, combined with the rural development programme of the ILO.

Other international organizations followed the changes at the ILO, as von Broembsen and Harvey show. Since 2011 new international instrumentsprimarily guidelines or soft laws to protect home workers-have been developed by the United Nations (UN) and the Organization for Economic Cooperation and Development (OECD). Together with the ILO Convention, these are useful instruments at the disposal of home workers. They are limited recommendations which support the legitimacy of home workers' claims in global supply chains. By referring to the 2011 UN Guiding Principles on Businesses and Human rights, the OECD Declaration on International Investment and Multinational Enterprises indirectly endorses the need for protection of home workers. As per the UN approach, home workers are covered under the framework of human rights, with states and corporations bearing responsibility to respect and uphold human rights and to remedy the situation when violations occur. These two principles refer directly to the ILo Declaration of Fundamental Principles and Rights at work and the UN Declaration of Human rights. This holds businesses responsible for violations of human rights in different parts of the supply chains. Today, 147 countries adhere to the OECD guidelines. The OECD also has guidelines for specific sectors, such as the Due Diligence guidelines for the garment and footwear sector. According to von Broembsen and Harvey, the OECD instruments are the most effective as home workers' organizations can report on companies violating the guidelines.

The chapters by Nirathron as well as von Broembsen and Harvey deal with the results of regulation and the struggles for their implementation. In Thailand, historically speaking, home-based work changed from being concerned with agricultural production to industrial and service products, a process that was accompanied by the informalization of labour. Thai home workers organized themselves under Home-Net Thailand. Legal protection of home workers started in 2004 with the passing of a regulation. This was followed in 2010 by the Home Workers' Protection Act.

The case of Thailand shows the importance of continuous investigations to monitor the situation of home workers and the collection of statistics. More important than the guidelines analysed in von Broembsen and Harvey's chapter 
is the 2015 ILO focus on the development of regulations for home work, which forms part of the Recommendation on the Transition from Informal to Formal Economies. In the Thai case, home workers were informal workers-similar to home workers in India, South Africa, and Brazil. Since the enforcement of the 2010 Act they are protected by specific laws when working in industrial sectors, but work in the service sector is still excluded from the provisions of the Act. Issues connected with the transition from an informal to a formal economy include a mandate for the collection of statistics to make home work visible, the organizing of home workers, qualitative research on the conditions of home work, and minimum wages for home work. The Thai government has created a tripartite Homework Protection Committee which reports to the Ministry. Protection and promotion of home work falls under the protection of labour courts, and violations can be punished with fines and imprisonment. Similarly, as in the case of food workers in Chennai analysed by K. Kalpana in this volume ("Refusing Invisibility: Women Workers in Subcontracted Work in a South Indian City"), the social protection of home workers-including health care, income security, and personal development-have become an issue for the state, and therefore the struggles of home workers have become a part of larger struggles involving citizens versus the state.

Nevertheless, it should be noted that most laws concerning aspects of labour protection assume an employer-employee relationship, which poses a specific challenge to regulations related to home work. As shown by K. Kalpana in her contribution to this volume, alliances between home workers and unions, as well as the state, become necessary to handle this situation. This appears to have been a successful strategy in South Africa and Brazil.

The fact is that legislation and regulation are not enough if rights are to be ensured. These remain toothless unless they are systematically implemented and violations are regularly reported, which in turn requires active intervention on the part of the respective authorities. Moreover, home workers are excluded from bargaining between brands and transnational/trans-sectoral unions. If the economic contribution of home workers remains unrecognized, they will continue to be neglected and their need to organize ignored. 